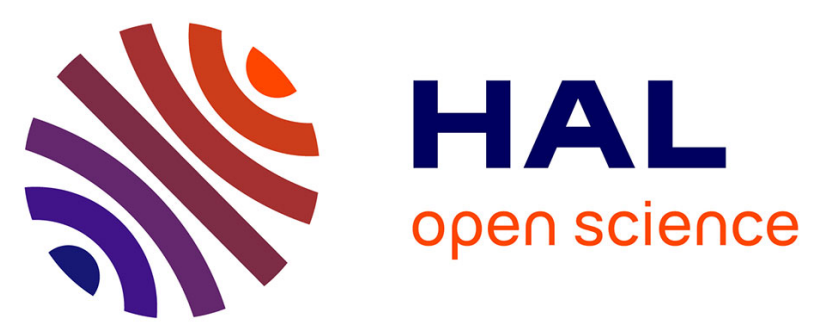

\title{
Selective Formation of Epoxylimonene Catalyzed by Phosphonyl/Arsonyl Derivatives of Trivacant Polyoxotungstates at Low Temperature
}

Ourania Makrygenni, Louise Vanmairis, Sabrina Taourit, Franck Launay, Alain Shum Cheong Sing, Anna Proust, Hélène Gérard, Richard Villanneau

\section{To cite this version:}

Ourania Makrygenni, Louise Vanmairis, Sabrina Taourit, Franck Launay, Alain Shum Cheong Sing, et al. Selective Formation of Epoxylimonene Catalyzed by Phosphonyl/Arsonyl Derivatives of Trivacant Polyoxotungstates at Low Temperature. European Journal of Inorganic Chemistry, 2019, 2020 (7), pp.605-612. 10.1002/ejic.201901152 . hal-02426557

\section{HAL Id: hal-02426557 \\ https: / hal.sorbonne-universite.fr/hal-02426557}

Submitted on 2 Jan 2020

HAL is a multi-disciplinary open access archive for the deposit and dissemination of scientific research documents, whether they are published or not. The documents may come from teaching and research institutions in France or abroad, or from public or private research centers.
L'archive ouverte pluridisciplinaire HAL, est destinée au dépôt et à la diffusion de documents scientifiques de niveau recherche, publiés ou non, émanant des établissements d'enseignement et de recherche français ou étrangers, des laboratoires publics ou privés. 


\title{
Selective Formation of Epoxylimonene catalyzed by Phosphonyle/Arsonyle Derivatives of trivacant polyoxotungstates at low temperature.
}

\author{
Ourania Makrygenni, ${ }^{[a]}$ Louise Vanmairis, ${ }^{[b]}$ Sabrina Taourit, ${ }^{[b]}$ Franck Launay, ${ }^{[c]}$ Alain Shum Cheong \\ Sing, ${ }^{*[\mathrm{~b}]}$ Anna Proust, ${ }^{[\mathrm{a}]}$ Hélène Gérard ${ }^{[\mathrm{d}]}$ and Richard Villanneau* ${ }^{[\mathrm{a}]}$
}

\begin{abstract}
The catalytic performances of three organophosphonyle/arsonyle derivatives of POMs were evaluated for the epoxidation of limonene in acetonitrile, using aqueous $\mathrm{H}_{2} \mathrm{O}_{2}$ as the oxidant. All three W-based POMs catalysts operated without any additional transitionmetal ions and displayed excellent conversion for the limonene to temperatures varying from 4 to $50^{\circ} \mathrm{C}$. Furthermore, the use of $\mathrm{B}, \alpha-\left[\mathrm{NaHAsW}_{9} \mathrm{O}_{33}\{\mathrm{P}(\mathrm{O}) \mathrm{R}\}_{2}\right]^{3-}\left(\mathrm{R}={ }^{t} \mathrm{Bu},-\mathrm{CH}_{2} \mathrm{CH}_{2} \mathrm{CO}_{2} \mathrm{H}\right)$ complexes led to the complete conversion of limonene to epoxylimonene at $4^{\circ} \mathrm{C}$. The selectivity of the reaction was modulated by varying the reaction solvent, and it was found that allylic reactions were favoured in ethanol. The effect of the catalyst protonation was also investigated by DFT calculations, highlighting the role of protons in the epoxidation process.
\end{abstract}

\section{Key Topic: Epoxidation with Polyoxometalates}

\section{Twitter address of the Institute [a]: https://twitter.com/InstitutUmr}

\section{Introduction}

The catalytic epoxidation of alkenes by hydrogen- or alkyl-peroxides is often considered as a model reaction in coordination chemistry. However, it is inexact and, in some respects, unfair to restrict this specific reaction to an "academic" tool for comparison of the catalysts performance. Indeed several chemical multi-steps processes of interest are based on the formation of organic epoxides, the most relevant being the formation of adipic acid from cyclohexene and of cyclic carbonates from the corresponding alkenes and $\mathrm{CO}_{2}$. The rationale for the use of polyoxometalates (POMs) in this context is justified by the research for efficient catalysts working in the mildest conditions. Indeed, various examples of epoxidation reactions catalyzed by heteropolytungstates without any additional transition-metal ions ${ }^{1}$ (including hybrid derivatives of $\mathrm{POMs})^{2,3}$ have been reported in the literature.

[a] Dr. O. Makrygenni, Prof. Dr. Pr A. Proust, Dr. R. Villanneau Sorbonne Université, CNRS, Campus Pierre et Marie Curie Institut Parisien de Chimie Moléculaire, CNRS UMR 8232 4 Place Jussieu, F-75005 Paris, France e-mail : richard.villanneau@sorbonne-universite.fr http://www.ipcm.fr/VILLANNEAU-Richard / https://orcid.org/0000 0003-1465-3494

[b] L. Vanmairis, S. Taourit, Dr. A. Shum Cheong Sing

Lab. de Chimie des Substances Naturelles et Sci. des Aliments Université de la Réunion, 15 Av. Henri Cassin, CS 92003, 97744

Saint-Denis cedex 9, France.

https://lcsnsa.univ-reunion.fr/accueil

[c] Prof. Dr. F. Launay

Sorbonne Université, CNRS, Campus Pierre et Marie Curie

Lab. de Réactivité de Surface, CNRS UMR 7197

4 Place Jussieu, F-75005 Paris, France

[d] Prof. Dr. H. Gérard

Sorbonne Université, CNRS, Campus Pierre et Marie Curie

Laboratoire de Chimie Théorique LCT- UMR 7616 ,

4 Place Jussieu, F-75005 Paris, France

Supporting information for this article is given via a link at the end of the document.
Protocols with hydrogen- or alkyl-peroxides involving efficient $\mathrm{W}(\mathrm{VI})$-peroxides catalytic species are generally characterized by negligible oxidant decomposition pathways and good to excellent selectivities. ${ }^{4}$ Some of us recently reported the promising catalytic performance of an organophosphonyle derivative of the arsenotungstate $\mathrm{B}, \alpha-\left\{\mathrm{AsW}_{9} \mathrm{O}_{33}\right\}^{9-}$, namely $\mathrm{B}, \alpha-\left[\mathrm{NaHAsW} \mathrm{O}_{33}\left\{\mathrm{P}(\mathrm{O}) \mathrm{CH}_{2} \mathrm{CH}_{2} \mathrm{CO}_{2} \mathrm{H}\right\}_{2}\right]^{3-}$ (figure 1). ${ }^{5}$ This particular compound has proved to be an efficient catalyst when used with $\mathrm{H}_{2} \mathrm{O}_{2}$ at room temperature.

Among the different substrates, terpenes are a natural class of compounds that can be found in large amounts in essential oils, used in food and beverage flavorings, perfumery and chemical industry. For instance, citrus essential oils (containing terpenes and, to a lesser extent, their oxygenated derivatives: alcohols, aldehydes, esters, ketones and a fewer amount of epoxides) are obtained from the peel with an overall yield in the range of 0.1 to $1 \%$, depending on the raw material. However, in the case of perfumery, terpenes such as limonene and $\beta$-pinene play a minor role in the aromas despite their presence in highest concentration. In this regard, processes for the sustainable production of higher value (oxygenated) terpenes derivatives from these citrus by-products are now explored and established. ${ }^{6}$ In this study, we focused on the catalytic transformation of the most abundant compounds, limonene preferentially, into the mono-epoxides. Indeed, the limonene oxides can be used as platform molecules for the synthesis of multifunctional bio-based polycarbonates polymers. ${ }^{7}$

In the present manuscript, a complete study of the catalytic performances of three different $\mathrm{POM}$ hybrids, namely $\mathrm{B}, \alpha-\left[\mathrm{NaHAsW}_{9} \mathrm{O}_{33}\{\mathrm{P}(\mathrm{O}) \mathrm{R}\}_{2}\right]^{3-}\left(\mathrm{R}={ }^{t} \mathrm{Bu}(1),-\mathrm{CH}_{2} \mathrm{CH}_{2} \mathrm{CO}_{2} \mathrm{H}(2)\right)$ and $\mathrm{A}, \alpha-\left[\mathrm{NaHPW} \mathrm{O}_{34}\left\{\mathrm{As}(\mathrm{O}) p-\mathrm{C}_{6} \mathrm{H}_{4} \mathrm{NH}_{2}\right\}_{2}\right]^{3-} \quad$ (3) anions, toward the epoxidation reaction of alkenes (cyclooctene, cyclohexene and limonene) is presented. Furthermore, DFT calculations were performed to address the localization of the catalytically active site, highlighting the role of the proton in the epoxidation process. In addition, the behavior of different catalysts toward the terpenic part of an essential oil deriving from sweet orange from Portugal was verified. 


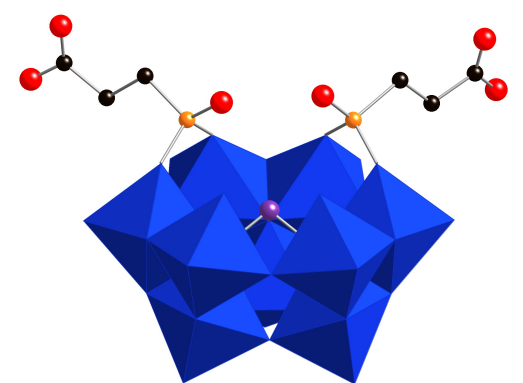

Figure 1. Structural representation of the $\mathrm{B}, \alpha-\left[\mathrm{AsW}_{9} \mathrm{O}_{33}\left\{\mathrm{P}(\mathrm{O}) \mathrm{CH}_{2} \mathrm{CH}_{2} \mathrm{CO}_{2} \mathrm{H}\right\}_{2}\right]^{5-}$ anion (2). $\mathrm{WO}_{6}$ polyhedra are shown in blue. The As, $\mathrm{P}, \mathrm{O}$ and $\mathrm{C}$ atoms are shown respectively in prune, orange, red and grey.

\section{Results and Discussion}

\section{Catalytic epoxidation of alkenes with ${\left({ }^{n-}\right.}^{-}$ $\left.\mathrm{Bu}_{4} \mathrm{~N}\right)_{3}\left[\mathrm{NaHAsW}_{9} \mathrm{O}_{33}\{\mathrm{P}(\mathrm{O}) \mathrm{R}\}_{2}\right]$}

Heteropolytungstates that do not contain any additional transition-metal ions, ${ }^{1}$ including organophosphonyle derivatives of POMs, ${ }^{2,3}$ have been extensively tested as catalysts precursors in alkenes epoxidation reactions with $\mathrm{H}_{2} \mathrm{O}_{2}$ as oxidant. ${ }^{8,9,10}$ Among these examples, only the group of Bonchio used organophosphonyle derivatives of trivacant POMs. However, the experimental conditions were quite drastic since it required a relatively high reaction temperature with microwave assistance. As a result, the need for a less energy-consuming approach is worth being investigated.

\subsection{Study of catalysts reactivity toward cyclooctene} including previously reported results. In this context, we recently synthesized and used a family of heteropolytungstates-based hybrids for their covalent immobilization onto the surface of various silica-based supports. ${ }^{11}$ The performances of these catalysts were first evaluated in the epoxidation of cyclooctene and cyclohexene with aqueous $\mathrm{H}_{2} \mathrm{O}_{2}$ as a model reaction, in homogeneous conditions or after their anchoring onto the support. ${ }^{5}$ In the course of this study, $\mathrm{B}, \alpha-\left[\mathrm{NaHAsW}_{9} \mathrm{O}_{33}\{\mathrm{P}(\mathrm{O}) \mathrm{R}\}_{2}\right]^{3-}(\mathrm{R}=$ $\mathrm{C}\left(\mathrm{CH}_{3}\right)_{3}={ }_{-}^{t} \mathrm{Bu} \quad$ (1), $\quad-\mathrm{CH}_{2} \mathrm{CH}_{2} \mathrm{CO}_{2} \mathrm{H} \quad$ (2)) and $\mathrm{A}, \alpha-\left[\mathrm{NaHPW}{ }_{9} \mathrm{O}_{34}\left\{\mathrm{P}(\mathrm{O}) p-\mathrm{C}_{6} \mathrm{H}_{4} \mathrm{NH}_{2}\right\}_{2}\right]^{3-} \quad$ (3) complexes demonstrated increased catalytic performances in homogeneous conditions. As one example, we have shown that the carboxylic acid-containing $\mathrm{B}, \alpha-\left[\mathrm{NaHAsW} \mathrm{O}_{33}\left\{\mathrm{P}(\mathrm{O}) \mathrm{CH}_{2} \mathrm{CH}_{2} \mathrm{CO}_{2} \mathrm{H}\right\}_{2}\right]^{3-}$ (2) derivative led to almost complete conversion of cyclooctene after $6 \mathrm{~h}$ at room temperature $(73 \%$ for cyclohexene after $24 \mathrm{~h}$, see figure 2$)$. The calculated turnover frequency (TOF) was ca. $45 \mathrm{~h}^{-1}$ when using a molar ratio of catalyst/alkene/ $\mathrm{H}_{2} \mathrm{O}_{2}$ equal to $1 / 250 / 250$. This TOF reached $300 \mathrm{~h}^{-1}$ at $50^{\circ} \mathrm{C}$ with an excess of $\mathrm{H}_{2} \mathrm{O}_{2}(3$ eq.) in regards to the substrate. This catalyst was also covalently grafted onto a $\left\{\mathrm{NH}_{2}\right\}$-functionalized mesoporous SBA-15 silica support. In these heterogeneous conditions, interesting conversions for both alkenes were maintained and, last but not least, a better epoxide selectivity for the cyclohexene, compared to the homogeneous conditions, was observed. $^{5}$

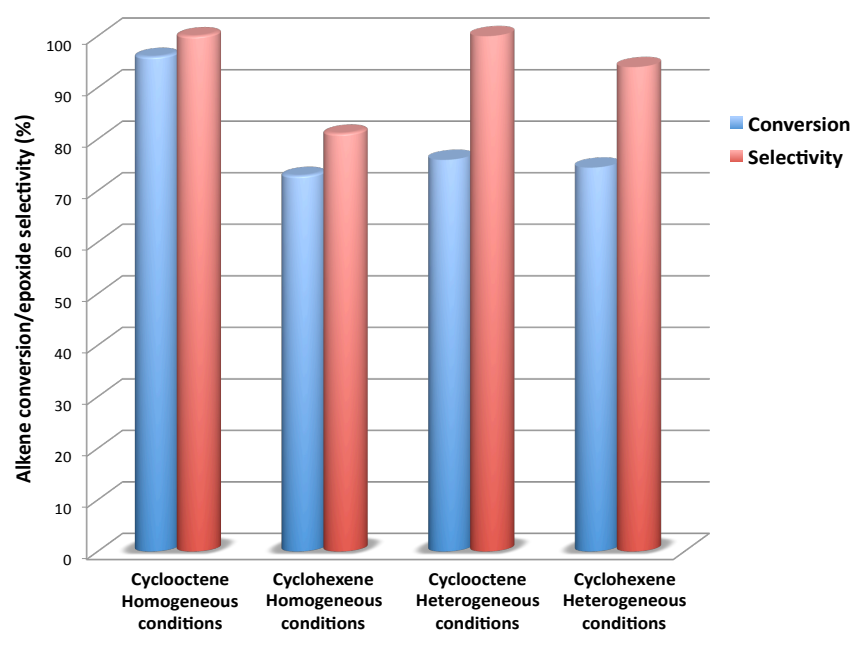

Figure 2. Conversion (in blue) and epoxide selectivity (in red) in the epoxidation of cyclooctene and cyclohexene with aqueous $\mathrm{H}_{2} \mathrm{O}_{2}$ using $\left({ }^{n}\right.$ $\left.\mathrm{Bu}_{4} \mathrm{~N}\right)_{3} \mathrm{NaH}\left[\mathrm{AsW}_{9} \mathrm{O}_{33}\left\{\mathrm{P}(\mathrm{O}) \mathrm{CH}_{2} \mathrm{CH}_{2} \mathrm{CO}_{2} \mathrm{H}\right\}_{2}\right]$ (2) in homogeneous and heterogeneous conditions, in acetonitrile, at room temperature. The molar ratios catalyst/alkene/ $\mathrm{H}_{2} \mathrm{O}_{2}$ were equal to $1 / 250 / 250$ after $24 \mathrm{~h}$.

For purpose of comparison, the catalytic performances of the corresponding tert-butyl derivative, first identified as $\left(^{n-}\right.$ $\left.\mathrm{Bu}_{4} \mathrm{~N}\right)_{3}\left[\mathrm{NaHAsW}{ }_{9} \mathrm{O}_{33}\left\{\mathrm{P}(\mathrm{O})^{t} \mathrm{Bu}\right\}_{2}\right]$, were also evaluated in the homogeneous epoxidation of cyclooctene (Table 1). ${ }^{5}$ In this first study, the behavior of both complexes (with $\mathrm{R}=$ $\mathrm{CH}_{2} \mathrm{CH}_{2} \mathrm{CO}_{2} \mathrm{H}$ and $-^{t} \mathrm{Bu}$ ) was different since for the latter the conversion was found very low $(7.5 \%)$ after one day at room temperature. With this catalyst, it is noteworthy that an increase of the temperature up to $50^{\circ} \mathrm{C}$ allowed the recovery of a similar catalytic efficiency to that of the carboxylic acid analogue.

We thus carried out additional investigations to determine the origin of such reactivity differences. Samples of the $\left[\mathrm{AsW}_{9} \mathrm{O}_{33}\left\{\mathrm{P}(\mathrm{O})^{t} \mathrm{Bu}\right\}_{2}\right]^{5-}$ anion were prepared with different degrees of protonation. In the first place, the monoprotonated $\left({ }^{n-} \mathrm{Bu}_{4} \mathrm{~N}\right)_{3}\left[\mathrm{NaHAsW}{ }_{9} \mathrm{O}_{33}\left\{\mathrm{P}(\mathrm{O})^{t} \mathrm{Bu}\right\}_{2}\right]$ (1) species was synthetized (see preparation in $\mathrm{SI}$ ) and the catalytic behavior of this new sample was found equivalent to that of other compounds (cyclooctene conversion $=100 \%$, at $20^{\circ} \mathrm{C}$ after $24 \mathrm{~h}$, see Table 1). In a second experiment, a sample of the protonated $\left({ }^{n-} \mathrm{Bu}_{4} \mathrm{~N}\right)_{3}\left[\mathrm{NaHAsW} \mathrm{O}_{9} \mathrm{O}_{33}\left\{\mathrm{P}(\mathrm{O})^{t} \mathrm{Bu}\right\}_{2}\right]$ (1) was treated with one equivalent of a methanolic solution $\left(1 \mathrm{~mol}^{-I^{-1}}\right)$ of ${ }^{n-}$ $\mathrm{Bu}_{4} \mathrm{NOH}$, leading to the in situ formation of the $\left[\mathrm{NaAsW} \mathrm{O}_{33}\left\{\mathrm{P}(\mathrm{O})^{t} \mathrm{Bu}\right\}_{2}\right]^{4-}$ anion. Using this sample for the cyclooctene epoxidation led to a dramatic decrease of the catalytic performances, attaining values obtained in our previous publication. ${ }^{5}$ It is, thus, possible to assign the previously reported results to the non-protonated $\left({ }^{n-}\right.$ $\left.\mathrm{Bu}_{4} \mathrm{~N}\right)_{4}\left[\mathrm{NaAsW} \mathrm{O}_{33}\left\{\mathrm{P}(\mathrm{O})^{t} \mathrm{Bu}\right\}\right]$ compound (see Table 1). Such synergetic process may be supported by previous studies by the group of Bonchio. It was shown that the catalyst efficiency was modulated through the protonation state of POMs (in their case $\left.\gamma-\left[\mathrm{SiW}_{10} \mathrm{O}_{36}\right]^{8-}\right) .{ }^{12}$ In addition, the groups of Kholdeeva and Poblet have recently emphasized the role of protons in heterolytic activation of $\mathrm{H}_{2} \mathrm{O}_{2}$ in the case of $\mathrm{Nb}$ substituted polyoxometalates, ${ }^{13}$ as it can be observed for mesoporous niobium silicates ${ }^{14}$ or $\mathrm{Zr}$-Based Metal-organic frameworks. ${ }^{15}$

Table 1. Comparison of the cyclooctene conversion (\%) in the epoxidation of cyclooctene with aqueous $\mathrm{H}_{2} \mathrm{O}_{2}(30 \%)$ after $24 \mathrm{~h}$ using the different 
catalysts. Catalyst: $24 \mu \mathrm{mol}$. Acetonitrile: $20 \mu \mathrm{mL}$. Ratio catalyst/cyclooctene/ $\mathrm{H}_{2} \mathrm{O}_{2}=1 / 250 / 250$.

\begin{tabular}{lccc}
\hline Catalysts & $\mathbf{T}\left({ }^{\circ} \mathbf{C}\right)$ & $(\%)$ & ref \\
\hline$\left({ }^{n-} \mathrm{Bu}_{4} \mathrm{~N}\right)_{3}\left[\mathrm{NaHAsW} \mathrm{O}_{33}\left\{\mathrm{P}(\mathrm{O}) \mathrm{CH}_{2} \mathrm{CH}_{2} \mathrm{CO}_{2} \mathrm{H}\right\}_{2}\right]$ & 20 & 96 & 5 \\
$(2)$ & 20 & 97 & 5 \\
$\left({ }^{n-} \mathrm{Bu}_{4} \mathrm{~N}\right)_{3}\left[\mathrm{NaHPW} \mathrm{O}_{34}\left\{\mathrm{P}(\mathrm{O}) p-\mathrm{C}_{6} \mathrm{H}_{4} \mathrm{NH}_{2}\right\}_{2}\right](3)$ & 20 & 7.5 & 5 \\
$\left({ }^{n-} \mathrm{Bu}{ }_{4} N\right)_{4}\left[\mathrm{NaAsW} \mathrm{O}_{9} \mathrm{O}_{33}\left\{\mathrm{P}(\mathrm{O})^{t} \mathrm{Bu}\right\}_{2}\right]$ & 50 & 100 & 5 \\
$\left({ }^{n-} \mathrm{Bu}{ }_{4} \mathrm{~N}\right)_{4}\left[\mathrm{NaAsW} \mathrm{O}_{9} \mathrm{O}_{33}\left\{\mathrm{P}(\mathrm{O})^{t} \mathrm{Bu}\right\}_{2}\right]$ & 20 & 100 & $\begin{array}{c}\text { This } \\
\text { work }\end{array}$ \\
$\left({ }^{n-} \mathrm{Bu} u_{4} \mathrm{~N}\right)_{3}\left[\mathrm{NaHAsW} \mathrm{O}_{9} \mathrm{O}_{33}\left\{\mathrm{P}(\mathrm{O})^{t} \mathrm{Bu}\right\}_{2}\right](1)$ & & &
\end{tabular}

1.2. Theoretical insight in the exact localization of the proton in $\left({ }^{n}{ }^{-} \mathrm{Bu}_{4} \mathrm{~N}\right)_{3}\left[\mathrm{NaHAsW} \mathrm{O}_{93}\{\mathrm{P}(\mathrm{O}) \mathrm{R}\}_{2}\right]$

Having in mind these experimental results, we were interested in determining the nature of the catalytic site and especially the role of protons in the reactivity of the $\left({ }^{n}\right.$ $\left.\mathrm{Bu}_{4} \mathrm{~N}\right)_{3}\left[\mathrm{NaHAsW}_{9} \mathrm{O}_{33}\{\mathrm{P}(\mathrm{O}) \mathrm{R}\}_{2}\right]$ compounds $(\mathrm{R}=$ $\mathrm{CH}_{2} \mathrm{CH}_{2} \mathrm{CO}_{2} \mathrm{H}$, ${ }^{t} \mathrm{Bu}$ ). A DFT study was thus carried out (see experimental part for computational details) aiming at analyzing the energetic and structural factors associated to the protonation of the phosphonyle polyoxoanions. This was first carried out on a slightly simplified model of the anionic part of the compound, namely $\left[\mathrm{NaHAsW}_{9} \mathrm{O}_{33}\left\{\mathrm{P}(\mathrm{O}) \mathrm{CH}_{3}\right\}_{2}\right]^{3-}$. Working on such highly charged species can be justified by the non-coordinating nature of the counter ions $\left({ }^{n-} \mathrm{Bu}_{4} \mathrm{~N}^{+}\right)$.

In a general way, the $\left[\mathrm{NaAsW}_{9} \mathrm{O}_{33}\{\mathrm{P}(\mathrm{O}) \mathrm{R}\}_{2}\right]^{4-}$ anions are obtained though the grafting of two phosphonyle groups onto four oxygen atoms from the lacuna of the $\mathrm{B}, \alpha-\left\{\mathrm{AsW}_{9} \mathrm{O}_{33}\right\}^{9-}$ unit. Consequently, the two free $\mathrm{O}$ atoms of the lacuna are strongly nucleophilic. Furthermore, the two $\mathrm{O}$ atoms from the $\{R P=O\}$ functions present nucleophilic properties, as shown before. ${ }^{11,16}$ For this reason, we have considered that the $\mathrm{Na}^{+}$ cation was located inside the lacuna and linked to these four $\mathrm{O}$ atoms, a location which was found as a minimum (Figure 3 ) by DFT calculations (see Computational details). Despite the absence of X-ray diffraction structural determination available for the family of compounds $\left({ }^{n-}\right.$ $\left.\mathrm{Bu}_{4} \mathrm{~N}\right)_{3}\left[\mathrm{NaHAsW}_{9} \mathrm{O}_{33}\{\mathrm{P}(\mathrm{O}) \mathrm{R}\}_{2}\right],{ }^{17}$ the coordination of $\mathrm{Na}^{+}$is in line with the partial structure determined by $\mathrm{X}$-Ray crystallography obtained on $\left({ }^{n-} \mathrm{Bu}_{4} \mathrm{~N}\right)_{3}\left[\mathrm{NaHPW}_{9} \mathrm{O}_{34}\{\mathrm{As}(\mathrm{O}) p\right.$ $\left.\mathrm{C}_{6} \mathrm{H}_{4} \mathrm{NH}_{2}\right\}_{2}$ ] (3). ${ }^{16}$ In contrast, in the absence of experimental elements, the position of the $\mathrm{H}^{+}$counterion had to be determined computationally. This was carried out through geometry optimization of the regioisomers differing from the proton position (see figure S1 for complete results). The isomers where the proton is localized on one of the two nucleophilic $\mathrm{O}$ atoms that delimit the lacuna (Figure 3 ) are the most stable. This is in accordance with the experimental results obtained by the group of Mizuno in the case of other lacunary POMs such as $\left[\gamma-\left\{\mathrm{SiW}_{10} \mathrm{O}_{32}\left(\mathrm{H}_{2} \mathrm{O}\right)_{2}\right\}_{2}(\mu-\mathrm{O})_{2}\right]^{4-}$. $^{18}$ The presence of the proton is shown to significantly lengthen the $\mathrm{Na} . . . \mathrm{O}(\mathrm{H}) \mathrm{W}$ distance, compared to when the proton is absent (Figure 3). In conclusion, it is probably more accurate to consider one $\{\mathrm{W}=\mathrm{O}\}$ group that delimit the lacuna of the $\left\{\mathrm{XW}_{9}\right\}$ scaffold as a $\{\mathrm{W}-\mathrm{OH}\}$ group. Further insight within the formation of the catalytically active site was sought through examination of the interaction of $\mathrm{H}_{2} \mathrm{O}_{2}$ with the lacuna.
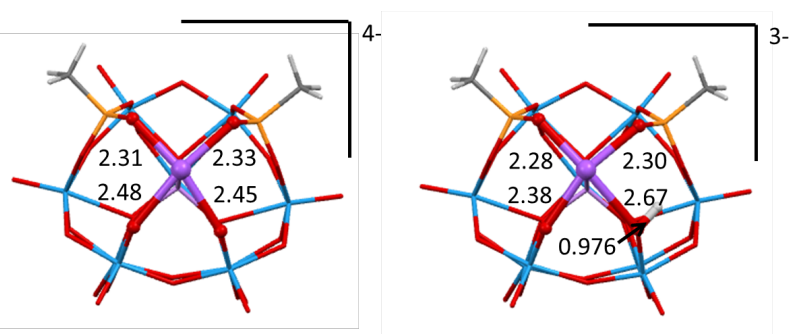

Figure 3: Optimized structure of the $\left[\mathrm{NaAsW}_{9} \mathrm{O}_{33}\left\{\mathrm{P}(\mathrm{O}) \mathrm{CH}_{3}\right\}_{2}\right]^{4-}$ (left) and $\left[\mathrm{NaHAsW}{ }_{9} \mathrm{O}_{33}\left\{\mathrm{P}(\mathrm{O}) \mathrm{CH}_{3}\right\}_{2}\right]^{3-}$ (right) anions showing the location of the $\mathrm{Na}^{+}$ cation (violet) inside the lacuna of the anion and of the proton (white) on one of nucleophilic WO. All the atoms - W (in blue), O (in red), As (in prune), $\mathrm{P}$ (in orange), $\mathrm{C}$ (in grey), $\mathrm{H}$ (in white) - are represented in stick mode, except for the lacuna (ball and sticks). Distances within the ball and stick part are in $\AA$.

\subsection{Theoretical examination of the interaction of $\mathrm{H}_{2} \mathrm{O}_{2}$ with \\ $\left.\mathrm{Bu}_{4} \mathrm{~N}\right)_{3}\left[\mathrm{NaHAsW} \mathrm{O}_{33}\left\{\mathrm{P}(\mathrm{O}) \mathrm{CH}_{3}\right\}\left\{\mathrm{P}(\mathrm{O}) \mathrm{CH}_{2} \mathrm{CH}_{2} \mathrm{COOH}\right\}\right]$}

Regarding the literature and the impact of acetic acid in epoxidation processes, ${ }^{19}$ it was also interesting to determine whether the presence of carboxylic acid functions found on the hybrid of POM could affect the chemical process. To carry out this theoretical study, one $\mathrm{CH}_{3}$ group of $\left[\mathrm{NaAsW}_{9} \mathrm{O}_{33}\left\{\mathrm{P}(\mathrm{O}) \mathrm{CH}_{3}\right\}_{2}\right]^{4-}$ was replaced by a $\mathrm{CH}_{2} \mathrm{CH}_{2} \mathrm{CO}_{2} \mathrm{H}$ group. In this case, a similar structure was obtained for the protonated

product $\left[\mathrm{NaAsW} \mathrm{O}_{32}(\mathrm{OH})\left\{\mathrm{P}(\mathrm{O}) \mathrm{CH}_{3}\right\}\left\{\mathrm{P}(\mathrm{O}) \mathrm{CH}_{2} \mathrm{CH}_{2} \mathrm{COOH}\right\}\right]^{3-}$ (designed as $\{\mathrm{W}-\mathrm{OH}\}$, see figure 4 , top/left and figure S2 for complete results), and no significant impact of the carboxylic acid function was observed at this stage. In particular, as only one carboxylic acid arm was added (see Figure 4), this simplification obviously led to a dissymmetry. However, we found that the coordination of the proton on one or the other $\{\mathrm{W}=\mathrm{O}\}$ group of the lacuna differed by less than $0.1 \mathrm{kcal}^{\mathrm{mol}}{ }^{-1}$. Furthermore, the most stable structure resulting from the transfer of the carboxylic acid proton onto the second $\{\mathrm{W}=\mathrm{O}\}$ group of the lacuna was found to be more than $15 \mathrm{kcal}^{\mathrm{mol}}{ }^{-1}$ higher in energy. Consequently, the possibility for transprotonation from the $\mathrm{CH}_{2} \mathrm{CH}_{2} \mathrm{CO}_{2} \mathrm{H}$ chain to the POM framework was definitively discarded.

In a second step, the interaction of $\mathrm{H}_{2} \mathrm{O}_{2}$ with the $\left[\mathrm{NaAsW}_{9} \mathrm{O}_{32}(\mathrm{OH})\left\{\mathrm{P}(\mathrm{O}) \mathrm{CH}_{3}\right\}\left\{\mathrm{P}(\mathrm{O}) \mathrm{CH}_{2} \mathrm{CH}_{2} \mathrm{COOH}\right\}\right]^{3-} \quad$ model compound was examined. Thus, the formation of a hydroperoxide site $\{\mathrm{W}-\mathrm{OOH}\}$ (associated to a free water molecule), instead of the $\{\mathrm{W}-\mathrm{OH}\}$ group, was found to be quasi athermic. Moreover, it can be stabilized by more than $10 \mathrm{kcal} . \mathrm{mol}^{-1}$ through coordination of water to the $\mathrm{Na}^{+}$center (figure 4, top/right).

On the other hand, the formation of a peracid function on the carboxylic acidic arm was slightly less favored than the formation of the hydroperoxide $\left(+1.4 \mathrm{kcal}^{\mathrm{mol}}{ }^{-1},\{\mathrm{CO}-\mathrm{OOH}\}\right.$ figure 4 , bottom/left). This preference did not change when $\mathrm{H}_{2} \mathrm{O}$ was bound to $\mathrm{Na}^{+}$(total: $+2.7 \mathrm{kcal} \mathrm{mol}^{-1}$, see Table S3).

Finally, the formation of a peroxo-hydroxo pair (designed as $\{\mathrm{W}-\mathrm{OO}\}$ figure 4 , bottom/right, and figure S4 for complete studies) after proton transfer from the hydroperoxide to the other $\{\mathrm{W}=\mathrm{O}\}$ site of the lacuna, was also

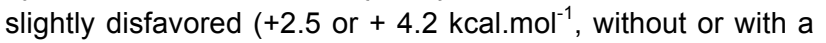
water molecule coordinated on the $\mathrm{Na}^{+}$cations respectively). Despite these small energy differences, and considering: 
- i) the catalytic activities of the protonated and unprotonated form of the $\left[\mathrm{NaAsW}_{9} \mathrm{O}_{33}\{\mathrm{P}(\mathrm{O}) \mathrm{R}\}_{2}\right]^{4-}$ anions on the one hand,

- ii) the catalytic activities of the different $\left[\mathrm{NaHAsW}_{9} \mathrm{O}_{33}\left\{\mathrm{P}(\mathrm{O}) \mathrm{R}_{2}\right]^{3-}\right.$ anions on the other hand, it can be suggested that the true catalytic center for the epoxidation reaction is the hydroperoxylated $\{\mathrm{W}-\mathrm{OOH}\}$ form, even in the case where $\mathrm{R}=-\mathrm{CH}_{2} \mathrm{CH}_{2} \mathrm{COOH}$.
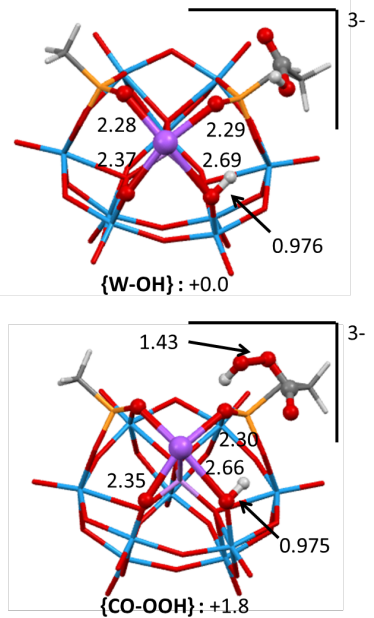

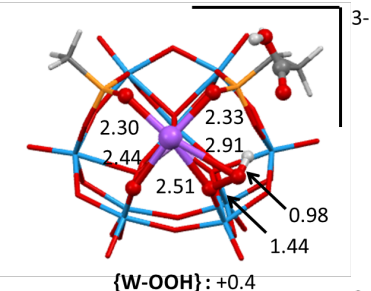

$\{\mathbf{W}-\mathbf{0 0}\}:+2,9$

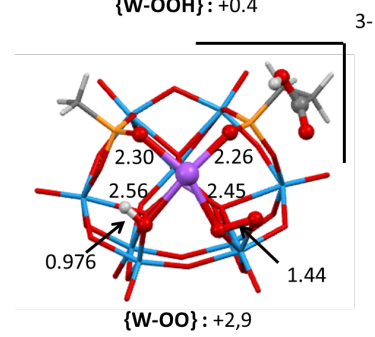

Figure 4: Optimized structure of the $\left[\mathrm{NaAsW}_{9} \mathrm{O}_{32}(\mathrm{OH})\left\{\mathrm{P}(\mathrm{O}) \mathrm{CH}_{3}\right\}\left\{\mathrm{P}(\mathrm{O}) \mathrm{CH}_{2} \mathrm{CH}_{2} \mathrm{COOH}\right\}\right]^{3-}$ anion ( $\{\mathrm{W}-\mathrm{OH}\}$, top/left) and of its potential products of reaction with $\mathrm{H}_{2} \mathrm{O}_{2}$ : $\left[\mathrm{NaAsW} \mathrm{O}_{32}(\mathrm{OOH})\left\{\mathrm{P}(\mathrm{O}) \mathrm{CH}_{3}\right\}\left\{\mathrm{P}(\mathrm{O}) \mathrm{CH}_{2} \mathrm{CH}_{2} \mathrm{COOH}\right\}\right]^{3-}$ ( $\{\mathrm{W}-\mathrm{OOH}\}$, top/right), $\left[\mathrm{NaAsW}_{9} \mathrm{O}_{32}(\underline{\mathrm{OH}})\left\{\mathrm{P}(\mathrm{O}) \mathrm{CH}_{3}\right\}\left\{\mathrm{P}(\mathrm{O}) \mathrm{CH}_{2} \mathrm{CH}_{2} \mathrm{COOOH}\right\}\right]^{3-} \quad(\{\mathrm{CO}-\mathrm{OOH}\}$, bottom/left) and $\left[\mathrm{NaAsW} \mathrm{O}_{31}(\mathrm{OH})(\mathrm{OO})\left\{\mathrm{P}(\mathrm{O}) \mathrm{CH}_{3}\right\}\left\{\mathrm{P}(\mathrm{O}) \mathrm{CH}_{2} \mathrm{CH}_{2} \mathrm{COOH}\right\}\right]^{3-}$ ( $\{\mathrm{W}-\mathrm{OO}\}$, bottom/right). Colour codes are similar to Figure 3 . Distances within the ball and stick part are in $\AA$ (not given if equal to the $\{\mathrm{W}-\mathrm{OH}\}$ distance). Energies of the reaction products $+\mathrm{H}_{2} \mathrm{O}$ are computed in kcal.mol ${ }^{-1}$ with respect to $\{\mathrm{W}-\mathrm{OH}\}+\mathrm{H}_{2} \mathrm{O}_{2}$.

2. Oxidation of limonene in the presence of the $\left(^{n-}\right.$ $\left.\mathrm{Bu}_{4} \mathrm{~N}\right)_{3}\left[\mathrm{NaHAsW}_{9} \mathrm{O}_{33}\{\mathrm{P}(\mathrm{O})(\mathrm{R})\}_{2}\right]$ (compounds 1 and 2) or $\left(^{n-}\right.$ $\left.\mathrm{Bu}_{4} \mathrm{~N}\right)_{3}\left[\mathrm{NaHPW}_{9} \mathrm{O}_{34}\left\{\mathrm{As}(\mathrm{O}) p-\mathrm{C}_{6} \mathrm{H}_{4} \mathrm{NH}_{2}\right\}_{2}\right]$ (3) catalysts. In the present work, the catalytic oxidation of bio-sourced molecules that are contained in essential oils of citrus has been also investigated. Indeed, citrus fruit is considered as one of the highest values fruits crops because of its good resistance during transport and storage phases. ${ }^{20}$ As a result, the essential oils obtained from the peel contain valuable components such as terpenes and, to a lesser extent, their oxygenated derivatives such as alcohols, aldehydes, esters, ketones and a few amounts of oxides. Part of the essential oil of citrus fruit, in particular unsaturated terpenic hydrocarbons such as limonene is undesirable for the cosmetics and perfumes industries. Limonene has been indeed classified as an allergen since the European Directive (2003/15/CE).

Furthermore, efficient and easy recovery processes of the terpenic fraction allowing the utilization of sustainable liquid-liquid extraction, in particular using ethanol/water mixtures, now exist. ${ }^{21}$ Our concern was then to devise sustainable production of higher value oxygenated derivatives of terpenes. In this regard, this study focused on the catalytic transformation of the most abundant compound, the limonene, preferentially into its corresponding mono-epoxides.

However, the oxidation of terpenes is particularly versatile. Various compounds can be obtained depending on the catalysts and/or the reaction conditions. ${ }^{22}$ In the case of limonene, the monoxide forms (cis-1,2-epoxylimonene and trans-1,2-epoxylimonene) are considered as valuable platform compounds, but alcohols (carveol), ketones (carvone), diols, aldehydes and over-oxidized forms (such as 1,2,8,9-diepoxylimonene) are systematically obtained as well (see figure 5). ${ }^{23}$

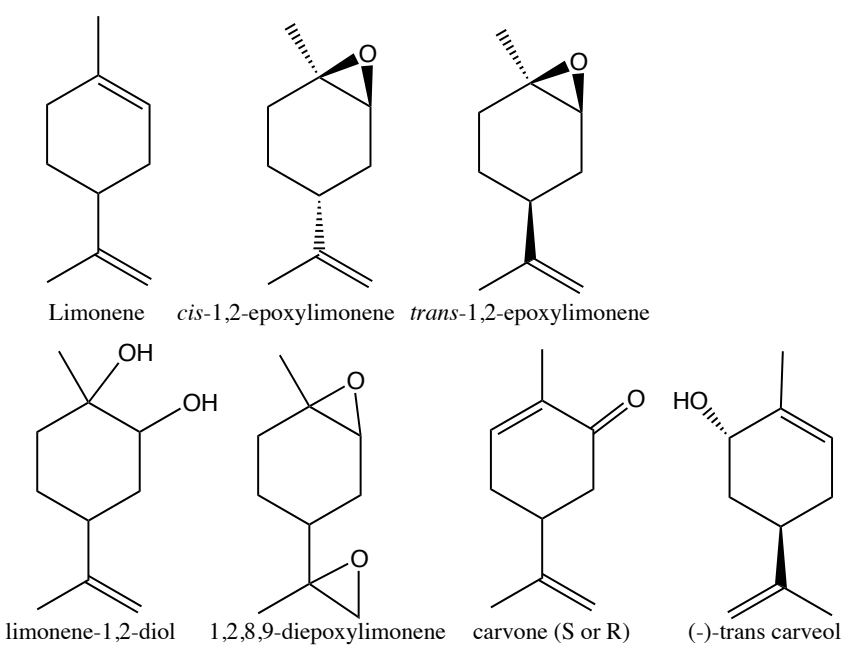

Figure 5. Limonene and most frequent oxidized forms of limonene.

\subsection{Selectivity of the epoxidation of pure $R(+)-$} limonene

Prior to the transformation of the citrus essential oil, we first performed an extended study on a commercial sample of $R(+)$-limonene, in order to check the catalytic performance of the $\left({ }^{n-} \mathrm{Bu}_{4} \mathrm{~N}\right)_{3}\left[\mathrm{NaHAsW}_{9} \mathrm{O}_{33}\left\{\mathrm{P}(\mathrm{O}) \mathrm{R}_{2}\right]^{3-}\left(\mathrm{R}=-\mathrm{C}\left(\mathrm{CH}_{3}\right)_{3}\right.\right.$ (1) or $\mathrm{CH}_{2} \mathrm{CH}_{2} \mathrm{CO}_{2} \mathrm{H}$ (2)) and $\left({ }^{n}{ }^{-} \mathrm{Bu}_{4} \mathrm{~N}\right)_{3}\left[\mathrm{NaHPW}_{9} \mathrm{O}_{34}\{\mathrm{As}(\mathrm{O}) p-\right.$ $\left.\mathrm{C}_{6} \mathrm{H}_{4} \mathrm{NH}_{2}\right\}_{2}$ ] (3) derivatives in the presence of the most abundant component of the oil. Due to slightly lower reactivity of limonene compared to simple cycloalkenes, all these catalytic tests were performed in acetonitrile with a two-fold excess of $\mathrm{H}_{2} \mathrm{O}_{2}$ with regard to the substrate (molar ratio of catalyst/alkene/ $\mathrm{H}_{2} \mathrm{O}_{2}$ equal to $1 / 250 / 500$ ). The effect of the temperature was also studied and tests were carried out at 4 , 25 and $50^{\circ} \mathrm{C}$. In all these experiments, the decomposition of $\mathrm{H}_{2} \mathrm{O}_{2}$ in the presence of the catalysts was not observed, and the mass balances for the organic derivatives were systematically determined using an internal standard (tetradecane).

In acetonitrile, all three hybrids of POMs led to high conversions of limonene at $25^{\circ} \mathrm{C}$, especially for $\left({ }^{n-}\right.$ $\left.\mathrm{Bu}_{4} \mathrm{~N}\right)_{3}\left[\mathrm{NaHAsW}_{9} \mathrm{O}_{33}\left\{\mathrm{P}(\mathrm{O})^{t}{ }^{-} \mathrm{Bu}\right\}_{2}\right] \quad$ (1) and $\left(^{n-}\right.$ $\left.\mathrm{Bu}_{4} \mathrm{~N}\right)_{3}\left[\mathrm{NaHAsW}_{9} \mathrm{O}_{33}\left\{\mathrm{P}(\mathrm{O}) \mathrm{CH}_{2} \mathrm{CH}_{2} \mathrm{CO}_{2} \mathrm{H}\right\}_{2}\right]$ (2), for which the cyclooctene conversions were respectively $95 \%$ and $100 \%$ after 24h. The aniline derivative $\left({ }^{n-}\right.$ $\left.\mathrm{Bu}_{4} \mathrm{~N}\right)_{3}\left[\mathrm{NaHPW}_{9} \mathrm{O}_{34}\left\{\mathrm{As}(\mathrm{O}) p-\mathrm{C}_{6} \mathrm{H}_{4} \mathrm{NH}_{2}\right\}_{2}\right]$ (3) displayed a more modest catalytic activity (conversion $=77 \%$ after $24 \mathrm{~h}$ ) than the two other POM catalysts. Furthermore, for this specific compound, prolonging the reaction up to $48 \mathrm{~h}$ did not increase significantly the limonene conversion (81\%), probably due to the deactivation/decomposition of the catalyst. This result is not particularly surprising since the $\left\{A, \alpha-P_{9}\right\}$ scaffold is generally considered to be less stable than the $\left\{B, \alpha-X^{\prime \prime \prime} W_{9}\right\}$ $(\mathrm{X}=\mathrm{As}, \mathrm{Sb})$ ones. $^{24}$ 
The catalytic results at 4,25 and $50^{\circ} \mathrm{C}$ with $\mathrm{B}, \alpha-\left[\mathrm{NaHAsW}{ }_{9} \mathrm{O}_{33}\left\{\mathrm{P}(\mathrm{O}) \mathrm{CH}_{2} \mathrm{CH}_{2} \mathrm{CO}_{2} \mathrm{H}\right\}_{2}\right]^{3-}$ (2) are reported in figure 6 (left).
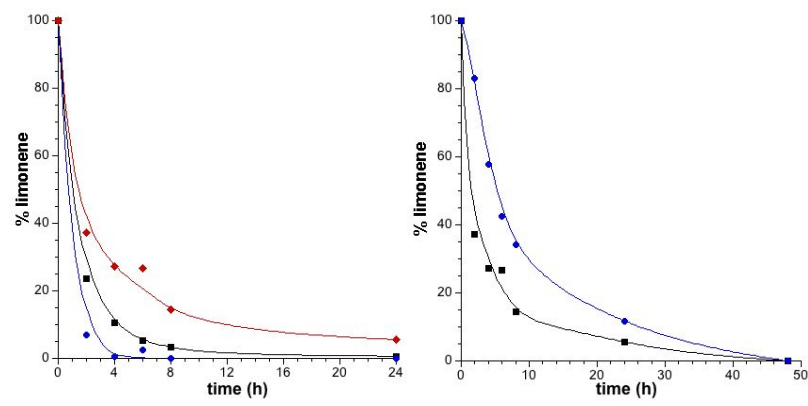

Figure 6. Left: time profiles of the limonene content in the presence of $\mathrm{H}_{2} \mathrm{O}_{2} /\left[\mathrm{NaHAsW}_{9} \mathrm{O}_{33}\left\{\mathrm{P}(\mathrm{O}) \mathrm{CH}_{2} \mathrm{CH}_{2} \mathrm{CO}_{2} \mathrm{H}\right\}_{2}\right]^{3-}$ (2) at $4^{\circ} \mathrm{C}$ (red), $25^{\circ} \mathrm{C}$ (black) and $50^{\circ} \mathrm{C}$ (blue). Right: time profiles of the limonene content at $4{ }^{\circ} \mathrm{C}$ in the presence of $\left[\mathrm{NaHAsW}_{9} \mathrm{O}_{33}\left\{(\mathrm{PO})^{t} \mathrm{Bu}\right\}_{2}\right]^{3-} \quad(1$ in blue $)$ and $\left[\mathrm{NaHAsW}_{9} \mathrm{O}_{33}\left\{\mathrm{P}(\mathrm{O}) \mathrm{CH}_{2} \mathrm{CH}_{2} \mathrm{CO}_{2} \mathrm{H}\right\}_{2}\right]^{3-}$ (2, in black).

With this catalyst, the reaction with $\mathrm{H}_{2} \mathrm{O}_{2}$ was completed after $8 \mathrm{~h}$ at $25^{\circ} \mathrm{C}\left(\mathrm{TOF}=95 \mathrm{~h}^{-1}\right)$ whereas it was completed after $4 \mathrm{~h}$ at $50^{\circ} \mathrm{C}\left(\right.$ TOF $\left.=116 \mathrm{~h}^{-1}\right)$. Furthermore, even at a low temperature $\left(4^{\circ} \mathrm{C}\right)$ both catalysts were still active (limonene conversion of $88 \%$ after $24 \mathrm{~h}$ for $\left({ }^{n-} \mathrm{Bu}_{4} \mathrm{~N}\right)_{3}\left[\mathrm{NaHAsW}_{9} \mathrm{O}_{33} 3^{t^{-}}\right.$ $\mathrm{BuPO}_{2}$ (1) and 95 \% for $\left({ }^{n-}\right.$ $\left.\mathrm{Bu}_{4} \mathrm{~N}\right)_{3}\left[\mathrm{NaHAsW}_{9} \mathrm{O}_{33}\left\{\mathrm{P}(\mathrm{O}) \mathrm{CH}_{2} \mathrm{CH}_{2} \mathrm{CO}_{2} \mathrm{H}\right\}_{2}\right]$ ) (2) and led to complete limonene conversions after two days (Fig. 6, right).

To our knowledge these are the first examples of POMbased catalytic systems that are efficient at such low temperature. Even if both catalysts are hardly as efficient as the classical iron(II) and iron (III) non porphyrinic systems (such as (poly)pyridyl, salen, benzylamine or heterocyclebased complexes) ${ }^{19}$ that operate at $0^{\circ} \mathrm{C}$, the present systems have the great advantage of not using acetic acid as a co-factor in the catalytic processes.

The selectivity in epoxides was also found strongly dependent on the temperature. Table 2 presents the yields for the different products in the oxidation of limonene at $25^{\circ} \mathrm{C}$ for the three catalysts.

Table 2. Yields (\%) for the reaction products in the oxidation of limonene with aqueous $\mathrm{H}_{2} \mathrm{O}_{2}$ in the presence of the 3 catalysts at $25^{\circ} \mathrm{C}$. Catalyst: 24 $\mu \mathrm{mol}$. Acetonitrile: $20 \mathrm{~mL}$. Ratio catalyst/imonene/ $\mathrm{H}_{2} \mathrm{O}_{2}=1 / 250 / 500$.

\begin{tabular}{lccccc}
\hline \multirow{2}{*}{ Catalysts } & \multicolumn{2}{c}{$\begin{array}{c}\text { 1,2-epoxy- } \\
\text { limonene }\end{array}$} & diol diepoxy & others \\
\cline { 2 - 5 } & trans & cis & & & \\
\hline$\left[\mathrm{NaHAsW}_{9} \mathrm{O}_{33}\left\{\mathrm{P}(\mathrm{O}) \mathrm{CH}_{2} \mathrm{CH}_{2} \mathrm{CO}_{2} \mathrm{H}\right\}_{2}\right]^{3-}$ & 76 & 7.5 & 4.5 & 3 & 9 \\
{$\left[\mathrm{NaHAsW}_{9} \mathrm{O}_{33}\left\{\mathrm{P}(\mathrm{O})^{\mathrm{t}} \mathrm{Bu}_{2}\right]^{3-}\right.$} & 47.5 & 6.0 & 7.5 & 13.5 & 20.5 \\
{$\left[\mathrm{NaHPW} \mathrm{O}_{34}\left\{\mathrm{As}(\mathrm{O}) p-\mathrm{C}_{6} \mathrm{H}_{4} \mathrm{NH}_{2}\right\}_{2}\right]^{3-}$} & 46.5 & 16.5 & 2.5 & 0.5 & 11.0 \\
\hline
\end{tabular}

At this temperature, the trans-1,2-epoxylimonene was always the major product of the reaction, but the selectivity did not exceed $76 \%$ for the most selective catalyst $\left(^{n-}\right.$ $\left.\mathrm{Bu}_{4} \mathrm{~N}\right)_{3}\left[\mathrm{NaHAsW}_{9} \mathrm{O}_{33}\left\{\mathrm{P}(\mathrm{O}) \mathrm{CH}_{2} \mathrm{CH}_{2} \mathrm{CO}_{2} \mathrm{H}_{2}\right]\right.$ in these conditions. Taking into account the cis-epoxide, the diepoxylimonene and the limonene-1,2-diol (which results from the opening of the oxirane ring) the sum of the selectivities into the monoepoxides and their derivatives are fairly good: $91 \%$ for $\left(^{n-}\right.$ $\left.\mathrm{Bu}_{4} \mathrm{~N}\right)_{3}\left[\mathrm{NaHAsW}_{9} \mathrm{O}_{33}\left\{\mathrm{P}(\mathrm{O}) \mathrm{CH}_{2} \mathrm{CH}_{2} \mathrm{CO}_{2} \mathrm{H}\right\}_{2}\right]$ (2), $78 \%$ for $\left({ }^{n-}\right.$ $\left.\mathrm{Bu}_{4} \mathrm{~N}\right)_{3}\left[\mathrm{NaHAsW}_{9} \mathrm{O}_{33}\left\{\mathrm{P}(\mathrm{O})^{t} \mathrm{Bu}_{2}\right]\right.$ (1) and $86 \%$ for $\left({ }^{n-}\right.$ $\left.\mathrm{Bu}_{4} \mathrm{~N}\right)_{3}\left[\mathrm{NaHPW}_{9} \mathrm{O}_{34}\left\{\mathrm{As}(\mathrm{O}) \mathrm{p}-\mathrm{C}_{6} \mathrm{H}_{4} \mathrm{NH}_{2}\right\}_{2}\right]^{3-}$ (3). However at this temperature, and a fortiori at the highest temperature tested $\left(50^{\circ} \mathrm{C}\right)$, the formation of products that came from allylic reactions (especially carvone and carveol) cannot be avoided. Moreover, decreasing the temperature down to $4^{\circ} \mathrm{C}$ for the two $\mathrm{B}, \alpha-\left[\mathrm{NaHAsW}_{9} \mathrm{O}_{33}\{\mathrm{P}(\mathrm{O}) \mathrm{R}\}_{2}\right]^{3-}$ catalysts led to excellent epoxide selectivities:

- for $\mathrm{R}=-\mathrm{C}\left(\mathrm{CH}_{3}\right)_{3}$ (1), the conversion at $24 \mathrm{~h}$ was $88 \%$ (100\% after $48 \mathrm{~h})$ with a selectivity for the trans-1,2epoxilimonene of $100 \%\left(\right.$ TOF $\left.=9 \mathrm{~h}^{-1}\right)$.

- for $\mathrm{R}=-\mathrm{CH}_{2} \mathrm{CH}_{2} \mathrm{CO}_{2} \mathrm{H}(2)$, the conversion at $24 \mathrm{~h}$ was $95 \%\left(\right.$ TOF $\left.=10 \mathrm{~h}^{-1}\right)$ with a final selectivity of $94 \%$ for the trans-1,2-epoxylimonene and $6 \%$ for the cis-epoxide.

With both catalysts, no products from allylic reactions were detected. The selective formation of epoxides/diols was expected for POMs that do not contain any additional transition-metal ions. Due to the presence of $d^{0}$ centers, these compounds are indeed good candidates for the (selective) electrophilic attack on double bond, ${ }^{25}$ rather than the alpha allylic oxidation or hydroxylation, that can lead respectively to the formation of carvone and carveol derivatives. In this regard, they combined at once very good conversion and selectivity, better than most of the classical epoxidation catalysts, such as heterogeneous silylated Ti-MCM-41 materials, which led to TOF up to $60 \mathrm{~h}^{-1}$ but at high temperature $\left(90^{\circ} \mathrm{C}\right.$ ) (limonene conversion $=89 \%$ after $24 \mathrm{~h}$, and 1,2 -epoxide selectivity $=78 \%) .{ }^{26}$ Comparison with the peroxotungstates complexes described in the literature (including the classical Ishii-Venturello system) is also in favor of the $\mathrm{B}, \alpha-\left[\mathrm{NaHAsW}_{9} \mathrm{O}_{33}\{\mathrm{P}(\mathrm{O}) \mathrm{R}\}_{2}\right]^{3-}$ anions. Indeed, such systems generally displayed lower catalytic performances at room temperature (for the limonene). ${ }^{27}$

Moreover, even if complete conversion and/or very good selectivity can be obtained with the Ishii-Venturello catalyst (at room temperature, limonene conversion $=94 \%$ after $1,5 \mathrm{~h}$, TOF $=125 \mathrm{~h}^{-1}$, limonene epoxide selectivity $=$ $97 \%$ ), this catalyst generally worked in harmful chlorinated solvents. ${ }^{28}$ In order to avoid such solvents, alternative strategies were proposed by certain groups, such as the use of eco-friendly bi/triphasic processes ${ }^{29}$ or the immobilization of the Ishii-Venturello catalyst onto macroreticular amberlite support. ${ }^{30}$ In this last study, this immobilization allowed the authors the use of $\mathrm{CH}_{3} \mathrm{CN}$, but resulted in a lower catalytic efficiency: at $\mathrm{T}=38^{\circ} \mathrm{C}$, limonene conversion $=84 \%$ after $24 \%$, and excellent selectivity for the monoepoxide $=93 \%$.

We also verified the reactivity of the $\left(^{n-}\right.$ $\left.\mathrm{Bu}_{4} \mathrm{~N}\right)_{3}\left[\mathrm{NaHAsW}{ }_{9} \mathrm{O}_{33}\left\{(\mathrm{PO})^{t} \mathrm{Bu}\right\}_{2}\right]$ (1) at $4^{\circ} \mathrm{C}$, in three other solvents: tetrahydrofuran (THF), ethyl acetate (AcOEt) and ethanol. In all cases (see Table 3), the reaction was slower than in acetonitrile but the limonene conversions after 2 days were rather satisfying (95\% in THF, 93 in AcOEt and $98 \%$ in ethanol). Concerning the other catalysts and the fact that they are much less soluble in these three solvents, it was not possible to evaluate their catalytic performances.

Table 3. Limonene conversion (\%) and yields (\%) for the reaction products in the oxidation of limonene with aqueous $\mathrm{H}_{2} \mathrm{O}_{2}$ in the presence of $\left(^{n-}\right.$ $\left.\mathrm{Bu}_{4} \mathrm{~N}\right)_{3}\left[\mathrm{NaHAsW}_{9} \mathrm{O}_{33}\left\{\mathrm{P}(\mathrm{O})^{t} \mathrm{Bu}_{2}\right]\right.$ (1) at $4^{\circ} \mathrm{C}$ in THF, AcOEt and ethanol after 48 h. Ratio catalyst/limonene/ $\mathrm{H}_{2} \mathrm{O}_{2}: 1 / 250 / 500$.

\begin{tabular}{|c|c|c|c|c|c|c|}
\hline \multirow[t]{2}{*}{ Solvent } & \multirow[t]{2}{*}{ Conv. (\%) } & \multicolumn{2}{|c|}{$\begin{array}{l}\text { 1,2-epoxy- } \\
\text { limonene }\end{array}$} & \multirow[t]{2}{*}{ diol } & \multirow[t]{2}{*}{ diepoxy } & \multirow[t]{2}{*}{ others } \\
\hline & & trans & cis & & & \\
\hline THF & 95 & 44.0 & 0 & 5.0 & 46.0 & 0 \\
\hline AcOEt & 93 & 24.3 & 0 & 55.7 & 8.7 & 0 \\
\hline Ethanol & 98 & 0 & 0 & 33.4 & 24.7 & 40.3 \\
\hline & $\mathrm{ca}$ & & & . & & \\
\hline
\end{tabular}


different in the three solvents: i) the trans-epoxylimonene was never the major constituent of the final mixture and the formation of the cis-isomer was never observed; ii) in THF, the epoxidation reaction was really efficient, even for the terminal alkene functions, with the major constituents being the 1,2,8,9-diepoxylimonene and the trans-1,2epoxylimonene; iii) the epoxides hydrolysis was favored in AcOEt (55.7 \% of diols); iv) surprisingly, allylic products were formed in large amounts $(40.3 \%)$ in ethanol, while the monoepoxides were not detected. This is an interesting result since it is possible to effectively guide the course of the reaction by simply modifying the temperature and/or the solvent.

2.2. Epoxidation of the terpene part of sweet orange essential oil at $4^{\circ} \mathrm{C}$ with $\left({ }^{n}-\mathrm{Bu}_{4} \mathrm{~N}\right)_{3}\left[\mathrm{NaHAsW}_{9} \mathrm{O}_{33}\left\{\mathrm{P}(\mathrm{O})^{t}{ }^{-} \mathrm{Bu}\right\}_{2}\right]$ (1).

We finally investigated the behavior of the $\left({ }^{n}\right.$ $\left.\mathrm{Bu}_{4} \mathrm{~N}\right)_{3}\left[\mathrm{NaHAsW}_{9} \mathrm{O}_{33}\left\{\mathrm{P}(\mathrm{O})^{t-} \mathrm{Bu}\right\}_{2}\right]$ catalyst (1) toward the terpene part (see deterpenation protocol in Experimental Section) of an essential oil of sweet orange from Portugal. Limonene is the major component of this fraction (90\%), but other compounds (especially monoterpenes such as $\alpha$-pinene, $\beta$-myrcene, sabinene, 3 -carene...) are also present. ${ }^{31}$ The oxidation of the pure essential oil was performed in conditions identical to those used for the limonene, with a catalyst/alkene/ $\mathrm{H}_{2} \mathrm{O}_{2}$ ratio equal to $1 / 250 / 500$ in acetonitrile at $4^{\circ} \mathrm{C}$, in order to optimize the potential formation of the different epoxides. We found that the oxidation of limonene in the essential oil was somewhat slower than starting from pure limonene in the course of time (conversion at $24 \mathrm{~h}$ equal to $71 \%$ for the essential oil, $88 \%$ in the case of pure limonene, see figure 7). Besides the remaining limonene, the main constituents of the mixture after oxidation were the trans-1,2epoxylimonene $(52 \%)$, the corresponding cis- isomer $(2 \%)$ and the compounds initially present in the mixture.

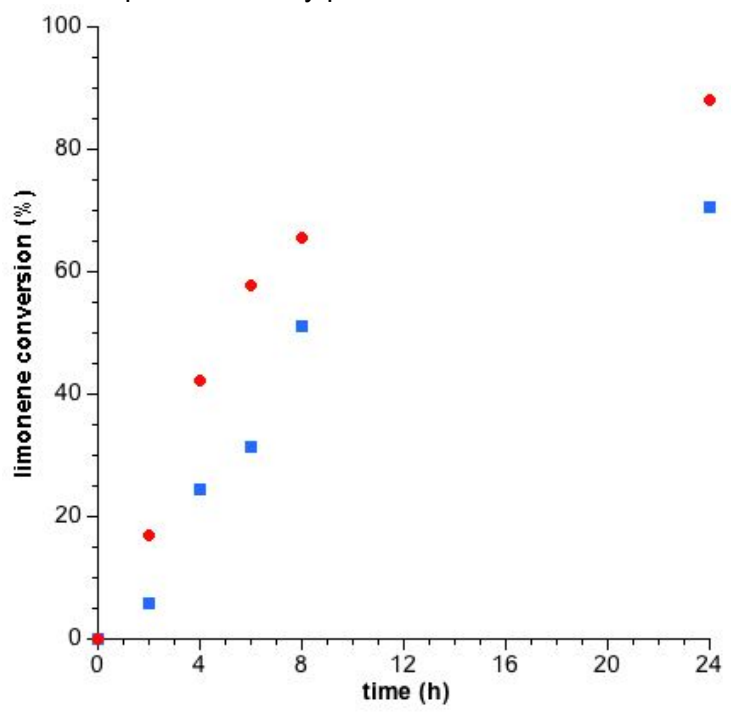

Figure 7. Time profile for limonene conversion starting from pure limonene (red dots) or sweet orange essential oil (blue square) with aqueous $\mathrm{H}_{2} \mathrm{O}_{2}$ in the presence of $\left.{ }^{n-} \mathrm{Bu}_{4} \mathrm{~N}\right)_{3}\left[\mathrm{NaHAsW}_{9} \mathrm{O}_{33}\left\{\mathrm{P}(\mathrm{O})^{t-} \mathrm{Bu}\right\}_{2}\right](1)$ at $4^{\circ} \mathrm{C}$ in acetonitrile.

No trace of oxidation products of the other initial components of the essential oil could be detected, excepted for $\alpha$-pinene, for which a weak amount of the corresponding epoxide was detected (less than 1\%). In particular $\beta$-pinene, the other main constituent of the essential oil, did not react with $\mathrm{H}_{2} \mathrm{O}_{2}$ in the presence of the catalyst. Thus, non-oxidized derivatives (remaining limonene, $\beta$-pinene...), $\alpha$-allylic oxidation and $\alpha$-allylic hydroxylation products represent $45 \%$ of the final mixture.

\section{Conclusions}

In the present study, the performances of organophosphonyle/arsonyle derivatives of POMs, i.e. $\left({ }^{n-}\right.$ $\left.\mathrm{Bu}_{4} \mathrm{~N}\right)_{3}\left[\mathrm{NaHAsW}_{9} \mathrm{O}_{33}\{\mathrm{P}(\mathrm{O}) \mathrm{R}\}_{2}\right] \quad\left(\mathrm{R}={ }^{t}{ }^{-} \mathrm{BuPO} \quad(1)\right.$ and $\mathrm{CH}_{2} \mathrm{CH}_{2} \mathrm{COOH}$ (2)) and $\left({ }^{n}-\mathrm{Bu}_{4} \mathrm{~N}\right)_{3}\left[\mathrm{NaHPW}_{9} \mathrm{O}_{34}\{\mathrm{As}(\mathrm{O}) p-\right.$ $\left.\left.\mathrm{C}_{6} \mathrm{H}_{4} \mathrm{NH}_{2}\right\}_{2}\right]$ (3), as terpenes epoxidation catalysts were explored. These complexes (to a lesser extent for $\left({ }^{n}\right.$ $\left.\mathrm{Bu}_{4} \mathrm{~N}\right)_{3}\left[\mathrm{NaHPW}_{9} \mathrm{O}_{34}\left\{\mathrm{As}(\mathrm{O}) p-\mathrm{C}_{6} \mathrm{H}_{4} \mathrm{NH}_{2}\right\}_{2}\right]$ ) showed a high efficiency for the conversion of limonene whatever the temperature used (from 4 to $50^{\circ} \mathrm{C}$ ). Indeed, $\left({ }^{n-}\right.$ $\left.\mathrm{Bu}_{4} \mathrm{~N}\right)_{3}\left[\mathrm{NaHAsW}_{9} \mathrm{O}_{33}\{\mathrm{P}(\mathrm{O}) \mathrm{R}\}_{2}\right]\left(\mathrm{R}=\mathrm{CH}_{2} \mathrm{CH}_{2} \mathrm{COOH}\right.$ and $\left.{ }^{t} \mathrm{Bu}\right)$ allowed the complete conversion of pure limonene at $50^{\circ} \mathrm{C}$ in a few hours in $\mathrm{CH}_{3} \mathrm{CN}$ (ca. $12 \mathrm{~h}$ at room temperature). As expected, the selectivity of this epoxidation reaction decreased by increasing the temperature. At $4^{\circ} \mathrm{C}$ in acetonitrile, the complete conversion of the limonene into the trans-epoxylimonene as the sole reaction product was observed after $48 \mathrm{~h}$ for the most selective catalyst $\left({ }^{n}\right.$ $\left.\mathrm{Bu}_{4} \mathrm{~N}\right)_{3}\left[\mathrm{NaHAsW} \mathrm{O}_{3}\left\{\mathrm{P}(\mathrm{O})^{t}{ }^{-} \mathrm{Bu}\right\}_{2}\right]$ (1). Moreover, varying the solvent allowed modulating the selectivity of the catalytic process, leading to the formation of products from allylic reactions (carvone and carveol) in ethanol.

A DFT study was performed in order to understand the role of protons in the $\left({ }^{n}{ }^{-} \mathrm{Bu}_{4} \mathrm{~N}\right)_{3}\left[\mathrm{NaHAsW}_{9} \mathrm{O}_{33}\{\mathrm{P}(\mathrm{O}) \mathrm{R}\}_{2}\right]-$ catalyzed epoxidation by $\mathrm{H}_{2} \mathrm{O}_{2}$. The exact localization of the protons associated to the anions in this family of complexes allowed the determination of the presence of a $\{\mathrm{W}-\mathrm{OH}\}$ group at the lacuna of these hybrids of POMs. It is highly likely that the reaction of hydrogen peroxide with the POMs occurs at this $\{\mathrm{W}-\mathrm{OH}\}$ group. However, no certainty on the mechanism can be drawn at this time on the basis of these sole thermodynamic considerations.

Finally, this study also highlighted that $\left({ }^{n}\right.$ $\left.\mathrm{Bu}_{4} \mathrm{~N}\right)_{3}\left[\mathrm{NaHAsW}_{9} \mathrm{O}_{33}\left\{\mathrm{P}(\mathrm{O})^{t}-\mathrm{Bu}\right\}_{2}\right]$ (1) was a very specific catalyst for the oxidation of limonene in natural extracts. In a more general way, phosphonyle derivatives of trivacant POMs displayed good limonene conversion and high selectivity in the epoxylimonene formation. This class of catalysts may thus be considered as ideal candidates for the scale up of the selective oxidation of terpenes such as limonene, and its development as practical biorefinery, i.e. as a facility that processes agricultural material (such as crop waste) to commercially useful chemicals. ${ }^{32}$

\section{Experimental Section}

\section{Materials and Methods}

The synthesis and the characterization of the $\left(^{n-}\right.$ $\left.\mathrm{Bu}_{4} \mathrm{~N}\right)_{3}\left[\mathrm{NaHAsW}_{9} \mathrm{O}_{33}\{\mathrm{P}(\mathrm{O}) \mathrm{R}\}_{2}\right] \quad\left(\mathrm{R}={ }^{t} \mathrm{Bu} \quad(1)\right.$ and $\mathrm{CH}_{2} \mathrm{CH}_{2} \mathrm{COOH}$ (1)) and $\left({ }^{n}-\mathrm{Bu}_{4} \mathrm{~N}\right)_{3}\left[\mathrm{NaHPW}_{9} \mathrm{O}_{34}\{\mathrm{As}(\mathrm{O}) p\right.$ $\left.\mathrm{C}_{6} \mathrm{H}_{4} \mathrm{NH}_{2}\right\}_{2}$ ] (3) catalysts were previously described. ${ }^{16}$ Solvents and other reagents were obtained from various commercial sources and used as received. $\mathrm{R}-(+)$-limonene (purity $>99 \%$ ) stabilized with BHT was purchased from Fluka, tetradecane (purity $>99 \%$ ) from Siccap emmop and the essential oil of sweet orange from Portugal was purchased 
from COOPER - Coopération Pharmaceutique Française, Melun, France (lot $N^{\circ}$ 04050164/B). The samples were analyzed by gas-phase chromatography coupled to an electron impact mass spectrometer $(70 \mathrm{eV})$. The different components were separated using a non-polar capillary column (Supelco SPB5, $60 \mathrm{~m}^{\star} 0,32 \mathrm{~mm}$, stationary phase $0,25 \mu \mathrm{m})$, with helium as the gas vector $\left(0.7 \mathrm{~mL} \cdot \mathrm{min}^{-1}\right)$. The injector temperature was fixed at $250^{\circ} \mathrm{C}$ in split mode $(1 / 50)$. The oven was initially set at $60^{\circ} \mathrm{C}$, increased until $250^{\circ} \mathrm{C}$ $\left(4^{\circ} \mathrm{C} \cdot \mathrm{min}^{-1}\right)$ for $50 \mathrm{~min}$, for a total duration of $97 \mathrm{~min}$. The identification of the different components was performed by comparison of their calculated retention indexes and of the corresponding mass spectra with data from the literature ${ }^{33}$ or available data banks (NIST, WILEY).

Computational Details. The calculations were carried out with the Gaussian 09 package of programs ${ }^{34}$ using the B3PW91 functional. ${ }^{35}$ Arsenic and tungsten were represented with the effective core potential SDDall ${ }^{36}$ from the Stuttgart group and the associated basis set. The $6-31 \mathrm{G}^{* *}$ basis set was used for all the other atoms $(\mathrm{H}, \mathrm{C}, \mathrm{O}, \mathrm{Na}$ and $\mathrm{P})$. Full geometry optimizations were carried out using a polarizable continuum model (SM, ${ }^{37}$ acetonitrile as a solvent) for solvation.

\section{Catalytic studies.}

The conditions used for the previously reported epoxidation of cyclooctene/cyclohexene are provided below. ${ }^{38}$

The limonene oxidation experiments were realized with a molar catalyst/limonene/ $\mathrm{H}_{2} \mathrm{O}_{2}$ ratio equal to $1 / 250 / 500$ at three different temperatures $\left(4^{\circ} \mathrm{C}, 25^{\circ} \mathrm{C}\right.$ and $\left.50^{\circ} \mathrm{C}\right)$.
In three vials, $\mathrm{R}-(+)$-limonene $(0.5 \mathrm{~mL}), \mathrm{H}_{2} \mathrm{O}_{2}(0.7 \mathrm{~mL}$ of a $30 \%$ wt. aqueous solution), and tetradecane $(0.45 \mathrm{~mL}$, internal standard) were successively added in $10 \mathrm{~mL}$ of acetonitrile. The catalyst (ca. $40 \mathrm{mg}$ ) was then added and the vials were finally sealed and stirred at their corresponding temperatures. Samples $(1.5 \mathrm{~mL})$ of each solution were taken after $2 \mathrm{~h}, 4 \mathrm{~h}, 6 \mathrm{~h}, 8 \mathrm{~h}$ et $24 \mathrm{~h}$ and mixed with $1.5 \mathrm{~mL}$ of pentane. The organic layer that contains the limonene and the oxygenated derivatives was removed, dried with $\mathrm{Na}_{2} \mathrm{SO}_{4}$ and injected $(0.08 \mu \mathrm{L})$ in GC/MS.

\section{Deterpenation protocol ${ }^{21}$}

The essential oil of sweet orange from Portugal $(10 \mathrm{~mL})$ was added to $30 \mathrm{~mL}$ of ethanol $(70 \% \mathrm{vol})$. This mixture was degased under $\mathrm{N}_{2}$ for $10 \mathrm{~min}$ and was stirred for 4 days at $4^{\circ}$ C. The suspension was then allowed to settle for 6 days. After separation, the terpene phase was mixed with water (1/1 volume) and solid $\mathrm{NaCl}$ was added in the mixture until saturation of the aqueous phase. After a few hours, the limpid organic phase was then separated using a separating funnel, dried with $\mathrm{Na}_{2} \mathrm{SO}_{4}$ and checked by GC-MS.

\section{Acknowledgments.}

This work was supported by the CNRS, Sorbonne Université and the Université de la Réunion. The authors also acknowledge support from the French Ministère de la Recherche et de l'Enseignement Supérieur for a PhD fellowship to Miss Ourania Makrygenni.

\footnotetext{
${ }^{1}$ N. Mizuno, K. Yamaguchi, K. Kamata, Coord. Chem. Rev. 2005, 249, 1944-1956.

2 S. Bernardi, M. Bonchio, M. Carraro, V. Conte, A. Sartorel, G. Scorrano, J. Org. Chem. 2007, 72, 8954-8957.

${ }^{3}$ M. Carraro, L. Sandei, A. Sartorel, G. Scorrano, M. Bonchio, Org. Lett. 2006, 8, 3671-3674.

${ }_{5}^{4}$ M. Amini, M. M. Haghdoost, M. Bagherzadeh, Coord. Chem. Rev. 2014, 268, 83-100.

${ }^{5}$ F. Bentaleb, O. Makrygenni, D. Brouri, C. Coelho Diogo, A. Mehdi, A. Proust, F. Launay, R. Villanneau, Inorg. Chem. 2015, 54, 7607-7616.

${ }^{6}$ E. V. Gusevskaya, ChemCatChem, 2014, 6, 1506-1515.

7 O. Hauenstein, S. Agarwal, A. Greiner, Nature Commun. 2016, 7, n: 111862.

${ }^{8}$ N. Mizuno, K. Kamata, K. Yamaguchi, Top. Catal. 2010, 53, 876-893.

${ }^{9}$ N. Mizuno, K. Kamata, Coord. Chem. Rev. 2011, 255, 2358-2370.

${ }^{10}$ Y. Goto, K. Kamata, K. Yamaguchi, K. Uehara, S. Hikichi, N. Mizuno, Inorg. Chem. 2006, 45, 2347-2356. A. Yoshida, M. Yoshimura, K. Uehara, S. Hikichi, N. Mizuno, Angew. Chem. 2006, 118, 1990-1994.

${ }_{11}^{11}$ R. Villanneau, A. Marzouk, Y. Wang, A. Ben Djamaa, G. Laugel, A. Proust, F. Launay, Inorg. Chem. 2013, 52, $2958-2965$.

${ }_{12}$ A. Sartorel, M. Carraro, A. Bagno, G. Scorrano, M. Bonchio, Angew. Chem. Int. Ed. 2007, 46, 3255-3258.

${ }^{13}$ N. V. Maksimchuk, G. N. Maksimov, V. Y. Evtushok, I. D. Ivanchikova, Y. A. Chesalov, R. I. Maksimovskaya, O. A. Kholdeeva, A. Solé-Daura, J. M. Poblet, J. J. Carbo, ACS Catal. 2019, 8, 9722-9737.

${ }^{14}$ I. D. Ivanchikova, I. Y. Skobelev, N. V. Maksimchuk, E. A. Paukshtis, M. V. Shashkov, O. A. Kholdeeva, J. Catal. 2017, 356, 85-99.

${ }^{15}$ N. V. Maksimchuk, J. S. Lee, M. V. Solovyeva, K. H. Cho, A. Shmakov, Y. A. Chesalov, J.-S. Chang, O. A. Kholdeeva, ACS Catal. 2019, 9, 9699-9704.

${ }^{16}$ R. Villanneau, A. Ben Djamâa, L.-M. Chamoreau, G. Gontard, A. Proust, Eur. J. Inorg. Chem. 2013, 1815-1820.

${ }_{17}$ C. R. Mayer, R. Thouvenot, J. Chem. Soc., Dalton Trans. 1998, 7-13.

${ }^{18}$ M. Yoshida, M. Yoshimura, K. Uehara, S. Hikichi, N. Mizuno, Angew. Chem. Int. Ed. 2006, 45, 1956-1960. N. Mizuno, K. Yamaguchi, Chem. Rec. 2006, 6, 12-22.

${ }^{19}$ M. C. White, A. G. Doyle, E. N.Jacobsen, J. Am. Chem. Soc. 2001,123, 7194-7195. G. Dubois, A. Murphy, T. D. Stack, Org. Lett. 2003, 5, 2469-2472. G. Olivo, O. Cusso, M. Costas, Chem. Asian J. 2016, 3148-3158 and references therein.

${ }^{20}$ Annual (2015) compilation of citrus fruit statistics, Food And Agriculture Organization of the United Nations, Rome, 2016.

21 J. Owusu-Yaw, R.F. Matthews, P.F. West J. food Sci. 1986, 51, 1180-1182. A. Guglielmone, Procédé d'extraction des huiles essentielles végétales par macération à froid et de déterpénation à froid, Brevet $n^{\circ}$ WO 1995003380 A1, 21 juillet 1993.

${ }^{22}$ C. Turek, F.C. Stinzing, Comp. Rev. Food Sci. Food Safety 2013, 12, 40-53; J.L. Bicas, A.P. Dionisio, G.M. Patore, Chem. Rev. 2009, 109, 4518-4531.

${ }^{23}$ B. Arizaga, A. de Leon, N. Burgueno, A. Lopez, D. Paz, N. Martinez, D. Lorenzo, E. Dellacassa, J. Bussi J Chem Technol Biotechnol 2007, 82, 532-538.

${ }^{24}$ T. Zhang, L. Mazaud, L.-M. Chamoreau, C. Paris, A. Proust, G. Guillemot, ACS Catal. 2018, 8, 2330-2342.
} 
${ }^{25}$ D. C. Duncan, R. C. Chambers, E. Hecht, C. L. Hill, J. Am. Chem. Soc. 1995, 117, 681-691.

${ }^{26}$ M. Guidotti, R. Psaro, I. Batonneau-Gener, E. Gavrilova, Chem Eng. Technol. 2011, 11, 1924-1927. C. Tiozzo, C. Bisio, F. Carniato, M. Guidotti, Catal. Today 2014, 235, 49-57.

${ }^{27}$ J.-M. Brégeault, R. Thouvenot, S. Zoughebi, L. Salles, A. Atlamsani, E. Duprey, C. Aubry, F. Robert, G. Chottard, Stud. Surf. Sci. Catal. 1994, 82, 571-581. E. Duprey, J. Maquet, P. P. Man, J.-M. Manoli, M. Delamar, J.-M. Brégeault, Appl. Catal. A: 1995, 128, 89-96. P. U. Maheswari, X. Tang, R. Hage, P. Gamez, J. Reedijk, J. Mol. Catal. A: Chem. 2006, 258, $295-301$. K. Kamata, K. Sugahara, R. Ishimoto, S. Nojima, M. Okazaki, T. Matsumoto, N. Mizuno, ChemCatChem 2014, 6, $2327-2332$. O. A. Kholdeeva, Eur. J. Inorg. Chem. 2013, 10-11, 1595-1605.

${ }^{28}$ S. Sakaguchi, Y. Nishiyama, Y. Ishii, J. Org. Chem. 1996, 61, 5307-5311.

29 J.-M. Brégeault, M. Vennat, L. Salles, J.-Y. Piquemal, Y. Mahhaa, E. Briot, P. C. Bakala, A. Atlamsani, R. Thouvenot, J. Mol. Cat. A: Chem. 2006, 250,177-189. I. V. Kozhevnikov, G. P. Mulder, M. C. Steverink-de Zoete, M. G. Oostwal, J. Mol. Cat. A: Chem. 1998, 134, 223-228.

${ }^{30}$ A. L. Villa de P., B. F. Sels, D. E. De Vos, P. A. Jacobs, J. Org. Chem. 1999, 64, 7267-7270.

31 J. Smadja, P. Rondeau, A. Shum Cheong Sing, Flavour Fragr. J. 2005, 20, 399-402

32 W.Piang-Siong, P. de Caro, C. Lacaze-Dufaure, A. Shum Cheong Sing, W. Hoareau, Ind. Crop. Prod. 2012, 35, $203-210$.

${ }^{33}$ R.P. Adams, Identification of essentials oil components by chromatography/quadrupole mass spectrometry; Carol Stream, Illinois, USA, Allured Publishing Corporation, 1995.

${ }^{34}$ Gaussian 09, Revision D.01, M. J. Frisch, G. W. Trucks, H. B. Schlegel, G. E. Scuseria, M. A. Robb, J. R. Cheeseman, G. Scalmani, V. Barone, G. A. Petersson, H. Nakatsuji, X. Li, M. Caricato, A. Marenich, J. Bloino, B. G. Janesko, R. Gomperts, B. Mennucci, H. P. Hratchian, J. V. Ortiz, A. F. Izmaylov, J. L. Sonnenberg, D. Williams-Young, F. Ding, F. Lipparini, F. Egidi, J. Goings, B. Peng, A. Petrone, T. Henderson, D. Ranasinghe, V. G. Zakrzewski, J. Gao, N. Rega, G. Zheng, W. Liang, M. Hada, M. Ehara, K. Toyota, R. Fukuda, J. Hasegawa, M. Ishida, T. Nakajima, Y. Honda, O. Kitao, H. Nakai, T. Vreven, K. Throssell, J. A. Montgomery, Jr., J. E. Peralta, F. Ogliaro, M. Bearpark, J. J. Heyd, E. Brothers, K. N. Kudin, V. N. Staroverov, T. Keith, R. Kobayashi, J. Normand, K. Raghavachari, A. Rendell, J. C. Burant, S. S. Iyengar, J. Tomasi, M. Cossi, J. M. Millam, M. Klene, C. Adamo, R. Cammi, J. W. Ochterski, R. L. Martin, K. Morokuma, O. Farkas, J. B. Foresman, and D. J. Fox, Gaussian, Inc., Wallingford CT, 2009.

${ }_{35}$ J. P. Perdew, Y. Wang, Phys. Rev. B 1992, 45, 13244-13249. A. D. Becke, J. Chem. Phys. 1993, 98, 5648-5652.

${ }^{36}$ D. Andrae, U. Häussermann, M. Dolg, H. Stoll, H. Preuss, Theor. Chim. Acta 1990, 77, 123-141. A. W. Ehlers, M. Böhme, S. Dapprich, A. Gobbi, A. Höllwarth, V. Jonas, K. F. Köhler, R. Stegmann, A. Veldkamp, G. Frenking, Chem. Phys. Lett. 1993, 208, 111-114.

${ }^{37}$ A. V. Marenich, C. J. Cramer, D. G. Truhlar, J. Phys. Chem. B 2009, 113, 6378-6396.

${ }^{38}$ Epoxidation of cyclooctene/cyclohexene: In homogeneous conditions, experiments of cyclooctene (or cyclohexene) epoxidation were performed in a $50 \mathrm{~mL}$ round-bottom flask equipped with a condenser and magnetic stirrer at room temperature or at $50^{\circ} \mathrm{C}$. The catalyst $\left(n-\mathrm{Bu}_{4} \mathrm{~N}\right)_{3} \mathrm{NaH}\left[\mathrm{NaHAsW} \mathrm{O}_{33}\left\{\mathrm{P}(\mathrm{O}) \mathrm{CH}_{2} \mathrm{CH}_{2} \mathrm{COOH}\right\}_{2}\right](80 \mathrm{mg}, 24 \mu \mathrm{mol} / 1 \mathrm{eq}$. $), 20 \mathrm{~mL}$ of acetonitrile, $0.78 \mathrm{~mL}$ of cyclooctene or $0.60 \mathrm{~mL}$ of cyclohexene $(6 \mathrm{mmol} / 250$ eq. $), 0.9 \mathrm{~mL}$ of decane (as an internal standard) and $0.6 \mathrm{~mL}$ of $\mathrm{H}_{2} \mathrm{O}_{2}(30 \% / 6 \mathrm{mmol} / 250 \mathrm{eq})$ were introduced successively in the flask. The resulting solutions were analysed by gas chromatography on a Delsi Nermag DN 200 GC apparatus equipped with a flame ionization detector and a MachereyNagel Optima-5 capillary column (length $30 \mathrm{~m}$, internal diameter $0.32 \mathrm{~mm}$, thickness $1 \mu \mathrm{m}$ ).

In heterogeneous conditions, experiments of cyclooctene/cyclohexene epoxidation were performed in three $5 \mathrm{~mL}$ flasks (for analysis at 3,6 and $24 \mathrm{~h})$ under stirring at room temperature. The solid catalyst ( $\mathrm{n}$ $\left.\mathrm{Bu}_{4} \mathrm{~N}\right)_{3} \mathrm{NaH}\left[\mathrm{NaHAsW} \mathrm{O}_{33}\left\{\mathrm{P}(\mathrm{O}) \mathrm{CH}_{2} \mathrm{CH}_{2} \mathrm{COOH}\right\}_{2}\right] @ S B A-\mathrm{NH}_{2}(40 \mathrm{mg})$, - corresponding to $1.2 .10^{-3} \mathrm{mmol} / 1$ eq. of POM - $1 \mathrm{~mL}$ of acetonitrile, $39 \mu \mathrm{L}$ of cyclooctene (250 eq.) or $30 \mu \mathrm{L}$ of cyclohexene (250 eq.), $45 \mu \mathrm{L}$ of decane and $30 \mu \mathrm{L}$ of $\mathrm{H}_{2} \mathrm{O}_{2}(30 \%, 250$ eq.) were introduced successively in each flask. The supernatant of the resulting suspensions was analyzed by gas chromatography as described above. 